\title{
Андрій КРИСОВАТИЙ
}

доктор економічних наук, профресор, Західноукраїнський національний університет,

Тернопіль, Україна, krysovatyy@gmail.com

ORCID ID: 0000-0002-5850-8224

\section{НОВИЙ ПРАГМАТИЗМ ФІСКАМІЗАЦІї ПУБАІЧНИХ ФIНАНСIB}

Вступ. Турбулентність у царині публічних фрінансів як у національному, так і у світовому масштабах засвідчує наявність невирішених проблем узгодженості постулатів наукового підгрунтя трансформації і розвитку інституту держави. Кризові явища початку двадиятого століття і пандемія 2019-2020 рр. розкрили неефективність ліберальних моделей державотворення, а тому доволі актуальними сьогодні є вектори активізації наукових зусиль, спрямованих на дослідження та вирішення вищеозначеної проблеми

Мета - систематизувати наукові підгрунтя новітніх теоретичних вимірів інституту публічних фрінансів та виокремити новий прагматизм їх фріскалізації.

Методи. У дослідженні використано методи діалектичного аналізу, синтезу та логічного узагальнення, а також порівняння і формалізації.

Результати. Розкрито сутнісні параметри взаємозв'язку глобальних кризових явищ і зміни технологічного укладу. Подано трактування фрінансової політики як мистецтва управління фрінансами задля створення умов для сталого соціально-економічного розвитку. Проаналізовано нагромаджені у сфрері фріскального простору та публічних фрінансів суперечності, здійснено моніторинг еволюції інституту держави. Доведено, що, враховуючи нові вектори суспільного розвитку, зумовлені кризою глобалізації і пандемії, доречно виокремити новий прагматизм фріскалізації публічних фрінансів, який визначатиметься цінностями, фрормальними і неформальними інститутами, а також політикою $i$ базуватиметься на головних засадах теорії збігу обставин розвитку.

Ключові слова: фрінансова політика, публічні фрінанси, фріскальний простір, бюджет, податки, державне регулювання, фрормальні і неформальні інститути, теорія збігу обставин.

Бібл.: 13.

\section{Андрей КРИСОВАТЫЙ}

доктор экономических наук, профрессор, Западноукраинский национальный университет, Тернополь, Украина

\section{НОВЫЙ ПРАГМАТИЗМ ФИСКААНЗАЦИИ ПУБАНЧНЫХ ФННАНСОВ}

Введение. Турбулентность в области публичных финансов как в национальном, так и в мировом масштабах свидетельствует о наличии нерешенных проблем согла-

(с) Андрій Ігорович Крисоватий, 2021 
сованности постулатов научного обоснования трансформации и развития института государства. Кризисные явления начала двадцатого века и пандемия 2019-2020 г2. вскрыли неэффективность либеральных моделей формирования государства, поэтому достаточно актуальными сегодня являются векторы активизации научных усилий, направленных на исследование и решение вышеобозначенной проблемы.

Цель - систематизировать научные обоснования новейших теоретических измерений института публичных фринансов и выделить новый прагматизм их фрискализации.

Методы. В исследовании использованы методы диалектического анализа, синтеза и логического обобщения, а также сравнения и формализации.

Результаты. Раскрыты истинные параметры взаимосвязи глобальных кризисных явлений и изменения технологического уклада. Предоставлена трактовка финансовой политики как искусства управления финансами для создания условий устойчивого социально-экономического развития. Проанализированы накопленные в сфрере фрискального пространства и публичных фринансов противоречия, осуществлен мониторинг эволюции института государства. Доказано, что, учитывая новые векторы общественного развития, вызванные кризисом глобализации и пандемии, уместно выделить новый прагматизм фискализации публичных финансов, который будет определяться ценностями, формальными и неформальными институтами, а также политикой и базироваться на главных чертах теории стечения обстоятельств развития.

Ключевые слова: фринансовая политика, публичные фринансы, фрискальное пространство, бюджет, налоги, государственное регулирование, фрормальные и неформальные институты, теория стечения обстоятельств.

\section{Andriy KRYSOVATYY}

Dr. Sc. (Economics), Prof., West Ukrainian National University, Ternopil, Ukraine, krysovatyy@gmail.com ORCID ID: 0000-0002-5850-8224

\section{NEW PRAGMATIC APPROACH TO FISCALIZATION OF PUBLIC FINANCE}

Introduction. Turbulence in the field of public finance on both national and global scale testifies to the existence of unresolved problems in reconciling the scientific postulates behind transformation and development of the institution of state. Crisis of the early twentieth century and the pandemic of 2019-2020 have revealed the ineffectiveness of liberal models of statehood, thus heightening the urgency of reinforcing scientific efforts directed at studying and fixing the aforementioned issue.

The purpose of the article is to systemize the scientific grounds of the latest theoretical dimensions of the public finance institute and to determine a new pragmatic approach to its fiscalization.

Methods. The methods of dialectic analysis, synthesis and logical generalization, as well as comparison and formalization are used.

Results. The essential parameters of the relationship between global crises and changes in the technological framework have been revealed. Financial policy is viewed as the art of managing finance with the purpose of creating conditions for sustainable socio-economic develop- 
ment. The contradictions accumulated in the field of public finance and fiscal space have been analyzed and the evolution of the institution of state has been traced. It has been proven that in view of the new directions of societal development precipitated by the globalization crisis and the pandemic it is advisable to determine a new pragmatic approach to fiscalization of public finance, which would be defined by values, formal and informal institutions, and policy based on the main features of the coincidence theory.

Keywords: financial policy, public finance, fiscal space, budget, taxes, state regulation, formal and informal institutes, coincidence theory.

JEL Classification: G20, G28, E62.

Постановка проблеми. Пандемія, пов'язана із коронавірусом, ще більше загострила проблеми кризи початку двадцять першого століття, а саме - кризи глобалізації. Відповідно до положень теорії збігу обставин розвитку [1], криза глобалізації в обов'язковому порядку призведе до заміни технологічного укладу. Технологічний уклад - це спосіб виробництва, який наразі існує у суспільстві. Тепер світ перебуває наприкінці п'ятого технологічного укладу - в економіці споживання, тобто економіці послуг і фінансових технологій посередництва. Турбулентність розвитку цивілізації, що розглядається в парадигмі науково-технічного процесу, наближає нас до освоєння шостого технологічного укладу, у якому за основу знову буде виробнича економіка, але яка базуватиметься повністю на штучному інтелекті та адитивних технологіях і характеризуватиметься нерівномірним змінним пришвидшеним розвитком нанобіоінженерій, заснованих на досягненнях природничих наук, квантових технологій, глобальних інформаційних мереж і цифрових технологій, інтегрованих високошвидкісних транспортних систем, нових видів і способів отримання енергії, когнітивних, соціогуманітарних, керованих психоемоційних технологій. Будь-яка зміна технологічного укладу - це переділ власності, боротьба нового капіталу, що базується на нових технологіях зі старим консерва- тивним капіталом. Перехід до шостого технологічного укладу базуватиметься на зміні світової політичної системи. До сьогодні існував Вашингтонсько-Брюссельський пакт про вільне переміщення людей, грошей, капіталів, товарів, послуг, інформації. За шостого технологічного укладу світ буде менш відкритим. Він рухатиметься до закритості і до згортання світової торгівлі в теперішньому її розумінні. Основу такого укладу становитиме віртуальний світ, де можна буде створювати і робочі місця, і вести торгівлю, і комунікувати, і що найдивовижніше, та одночасно найбільш суперечливе - навчатися і здобувати освіту онлайн/online education. У цьому плані коронавірус став каталізатором пришвидшення цих процесів. Великі кардинальні зміни із приходом шостого технологічного укладу відбудуться і у фрінансовому секторі суспільства. Блокчейн і створення електронних грошей, криптовалюти, керована соціалізація психоемоційного сприйняття фрінансових рішень повністю змінюють сутнісні наповнення фрінансових дефініцій і вимагають нового, прагматичного розуміння та переосмислення природи фінансової політики держави, публічних фрінансів і фріскального простору.

Аналіз останніх досліджень і публікацій. Наявні концепції становлення, функціонування та розвитку публічних фрінансів, над якими працювали впродовж тривалого 
часу учені й науковці, подані у сучасній науковій літературі значним доробком, стали підґрунтям для опрацювання нового прагматизму їхньої фріскалізації. В основу статті взято праці вітчизняних і зарубіжних науковців Г. Колодко [1], О. Кириленко [2], Т. Кізими [2], Н. Кравчук [2], О. Длугопольського [3], В. Суторміної [4], В. Федосова [5], В. Андрущенка [5], Ю. Шишкова [7], Дж. Сакса [9], Г. Копіца [11] та інші.

Трактування фрінансової політики, як певної діяльності державних органів, пов'язаних із використанням фрінансових відносин для виконання державою у широкому розумінні своїх функцій, містить у собі низку суперечливих моментів. Функції і завдання держави в особі центральних органів публічного управління та органів місцевого самоврядування трансформуються відповідно до існуючих у суспільстві уявлень про роль держави. Якщо сприймати фрінансову політику як систему формальних інститутів виконання функцій держави, без обґрунтування теоретичного підґрунтя надбання фінансової науки, тоді державна фінансова політика стає фрінансовою політикою окремої групи осіб - можновладців, які мають вплив на прийняття політичних рішень. А тому уже у змістовному наповненні дефрініції державної фрінансової політики необхідно закладати сутнісну тезу про те, що така політика має враховувати інтереси всіх суб'єктів фрінансової системи держави, а не тільки органів державної та місцевої влади. Ось чому державну фінансову політику потрібно розглядати як мистецтво управління фінансами задля створення умов для сталого соціально-економічного розвитку, зменшення нерівності розподілу багатства, підвищення рівня і якості життя населення.

Термін “публічні фінанси" увійшов до української фрінансової науки не так давно і загалом він ототожнюється в науковій та навчальній літературі 3 державними фрінансами в широкому сенсі, включаючи до останніх місцеві фрінанси [2]. Деякі науковці використовують термін "публічні фрінанси" в контексті визначення їх такими, що охоплюють доходи і видатки центрального та місцевого урядів, а також структурні взаємозв'язки між ними, визначення яких відбувається в середовищі представницької влади [3]. Новий прагматизм розгляду дефініції “публічні фрінанси” доцільно розглядати у контексті зміни технологічних укладів та еволюції, пов'язаної зі стиранням кордонів між національними суспільними відносинами та зовнішнім світом, що призводить, з одного боку, до поглиблення взаємодії приватного бізнесу та публічного сектору країни (державно-приватне партнерство), взаємодії публічного сектору однієї країни з публічним сектором іншої країни (міжнародні державні консорціуми та об'єднання), а з іншого - активізує діяльність державних і місцевих органів, державних фінансових корпорацій і фрінансових корпорацій, створених місцевими органами влади на внутрішніх і зовнішніх фінансових ринках (муніципальні, внутрішні та зовнішні запозичення).

Мета статті полягає у систематизації наукового підґрунтя новітніх теоретичних вимірів інституту публічних фрінансів та виокремленні нового прагматизму їх фіскалізації.

Виклад основного матеріалу дослідження. На сьогодні технології шостого технологічного устрою стають пріоритетними, а отже, і домінуючими у суспільстві. Перехід на ці технології $є$ болісним і супроводжується кризовими явищами соціальногуманітарного характеру. Очевидно, що можливість пом'якшення турбулентності таких процесів, які супроводжують зміну технологій, залежить не тільки від здатності генерувати проривні технології, а й від мобільності інституту держави та його здат- 
ності щодо реагування на виклики та загрози інтегрування і засвоювання позитивних інновацій шостого технологічного укладу.

Моніторинг нагромаджених у сфері публічних фрінансів суперечностей свідчить про те, що вітчизняний фіскальний простір не склався як єдине ціле, у якому узгоджені всі фрункціональні елементи. Реалії українського сьогодення у сфрері фріскального простору, які розглядають через призму глобалізаційної кризи неолібералізму, - це внутрішня неузгодженість складових цілісної системи бюджетних, міжбюджетних, боргових та податкових правовідносин. А також турбулентність світогосподарських зв'язків, нестабільність правового регламентування фріскальних відносин, складність адміністрування податків і податкових платежів, порушення принципів економічної, соціальної справедливості та рівномірності податкового навантаження, незадовільне вирішення фріскальних завдань через перекоси як в галузевому, так і територіальному аспектах, негативний вплив політики в сфері фіскальної політики на стан національної економіки, низький рівень податкової та бюджетної дисциплін.

Ще за часів Радянського Союзу фундаментальні дослідження Київської наукової фрінансової школи в особі В. Андрущенка, В. Суторміної, В. Федосова відрізнялися власним баченням причинно-наслідкових зв'язків у ссрері публічних фрінансів і особливо їх стержневого питання, своєрідної “першоклітини" - податку. 3 оподаткування розвивається вся складна система вилучення, розподілу і споживання фрінансових фондів, яка відповідає державним фінансам [4, с. 11-12]. Наукові постулати зазначених авторів у царині фріскального простору щодо ролі фріску у функціонуванні публічних фрінансів завжди залишаються актуальними. "Податки виникають на доволі високому рівні суспільного розвитку, бо вони вимагають загальновизнаних законів та норм громадянської поведінки, - інакше податки сприймаються як свавільна конфіскація приватної власності. Буржуазна цивілізація виробила відомі критерії оподаткування: справедливість, неупередженість, рівність, всеосяжність, платоспроможність. Додержання цих правил - необхідна умова здорового соціально-економічного розвитку, а порушення неминуче призводить до занепаду держави" [5, с. 28].

Дискурс навколо еволюції інституту держави та перспектив збереження ії суверенітету в епоху глобалізації не отримав однозначної оцінки в науковій літературі. Очевидним є лише одне - світ змінюється, і разом з ним змінюються уявлення про роль держави в міжнародних економічних відносинах. Упродовж кількох століть з часу виникнення державу (у своїй специфічній формі національної держави) розглядали як головний суб'єкт у міжнародних економічних відносинах. Регулювання світової економіки асоціювалося 3 діяльністю національних урядів, оскільки саме вони здійснювали юридичний контроль у межах своїх суверенних територій. Найбільш розвинуті в той чи інший період національні господарства значною мірою визначали характер, форми і механізми міжнародних відносин. Цілком обґрунтовано світову економіку розглядали як сукупність взаємопов'язаних національних економік. Торгівля і рух капіталу в світовій економіці були буквально інтернаціональними [6, c. 270]) в політичному, економічному і соціальному житті суспільства; “...відбувається трансформація цієї традиційної форми організації світового соціуму в дещо нову її форму" [7, с. 3]. Все це вкотре в контексті ретроспективи глобального розвитку актуалізує пошук відповіді на риторичні запитання: яка роль відводиться державі і якою має бути оптимальна модель ії фрінансової 
поведінки в сучасних умовах глобальних трансформацій? Чи справді глобальна конкуренція означає кінець національної фрінансової економічної політики та добробуту держави (welfarestate)? Держава загального добробуту (welfarestate) отримала поширення в країнах Західної Європи після Другої світової війни. Організаційно-правове зародження держави добробуту пов'язане 3 іменем англійського політичного діяча Уїльяма Беверіджа, пропозиції якого (план Беверіджа) в 1942 р. стали основою низки законів про державну систему медичного обслуговування та соціального забезпечення. На міжнародному рівні підставою для правового оформлення й практичної розбудови держави загального добробуту стали рішення Міжнародної організації праці (Філадельфія, 1944 р.) [8, с. 32].

Актуальність цього напрямку дослідження диктується тим, що сучасна практика трансформації фріскального простору надає переконливі свідчення тому, що процеси наукового обґрунтування виваженої концепції рефрормувань продовжують підмінятися безперспективним перетасовуванням складових фіскального простору. Методологічна помилка полягає у тому, що Україна знову підійшла до необхідності реформувати публічні фрінанси без практично розробленої відповідної соціально-економічної доктрини держави. Непослідовність виявляється у тому, що, з одного боку, декларується потреба підвищення теоретико-методологічного підґрунтя фріскальних рефрормувань, а з іншого - здійснюються спроби прийняття змін до Бюджетного та Податкового кодексів без розробки відповідної концепції. За такого підходу зрозумілі сумніви щодо можливостей розв'язання протиріч, які накопичилися у суспільній сфрері, та запобігання їх подальшому виникненню. По-перше, концепція реформування публічних фрінансів повинна чітко визна- чати, яким саме чином мають відбуватися зміни. Насамперед, це стосується напрямку реформування фріскального простору. Умовно його можна поділити на еволюційний, що не несе у собі кардинальних змін в короткостроковому плані, а є подальшим вдосконаленням податків, боргу та трансфрертів; та революційний, що передбачає одночасні глибокі зміни та перетворення. Звідси перше принципове питання, яке виникає в процесі корекції публічних фрінансів у контексті нинішнього стану фріскального простору, визначених концептуальних положень і критичного аналізу світових здобутків - чи спроможна сучасна фрінансова політика досягти необхідної ефективності еволюційним шляхом, чи необхідні їй докорінні перетворення. Відповідь на це запитання $є$ вирішальною і для розробки програми конкретних заходів як завершального етапу реалізації методологічної конструкції фрінансових реформувань, що зумовлено взаємозалежністю усіх ії̈ складових.

Сьогодні в Україні питання турбулентності фріскального простору належать до найгостріших як в економічному й соціальному, так і в політичному контексті. Фіскальна політика України поєднала в собі принципи двох фіскальних просторів, найбільш характерних для світової практики європейської та американської. При цьому, якщо в європейській системі переважає обкладання обороту у формі податку на додану вартість, то в американській - прибутковий принцип оподаткування. Складність вітчизняної фріскальної політики визначена еклектичним поєднанням обох зазначених просторів з базовою метою - забезпечення максимального рівня фріскальних надходжень, як основної складової дохідної частини бюджету.

Україна, не маючи достатнього практичного досвіду й наукового обґрунтування формування та реалізації публічних фрі- 
нансів, розвивалася експериментальним шляхом, нерідко роблячи при цьому хибні кроки. Введені податки та інші фріскальні інститути децентралізації певною мірою були новими радше за формою, ніж за змістом. Так чи інакше вони містили ознаки старої адміністративної системи, заснованої на надмірній централізації процесу формування та розподілу фінансових ресурсів держави. Це призвело до того, що акумулювання доходів бюджетів за рахунок податкових і боргових фрінансів відривалося від процесу господарювання платників податків. Відсутність універсальної методологічної концепції рефрормування стратегії і тактики публічних фрінансів, за якою можна було б розрахувати оптимально можливий та допустимий (як для держави, так і для платників податків) рівень податкового навантаження, призвела до сьогоднішньої ситуації, де за невисоких (порівняно з іншими країнами) податкових ставках безлад в адмініструванні податків, тіньова економіка, політичний лобізм, неконтрольовані обсяги внутрішніх та зовнішніх запозичень зводить нанівець забезпечення умов для економічного зростання. Головне завдання у цьому плані полягає в наповненні ринковим змістом форм вітчизняного фіскального простору, а це потребує зміни схеми й пропорцій розподілу та перерозподілу валового національного продукту на основі виваженої та прозорої податкової політики, яка оптимально враховувала б як фіскальні інтереси держави, об'єднаних територіальних громад, економічні інтереси суб'єктів господарювання, так і соціальні інтереси громадян.

Загальні міркування про роль публічних фрінансів в епоху кризи глобалізації малопродуктивні, якщо поза увагою залишається багатогранність і багаторівневість цієї проблеми (йдеться про основні тенденції еволюції держави в сучасному глобаль- ноцентричному світі; про зміну її функціонального призначення в епоху кризи глобалізації та ролі в регулюванні фрінансових процесів і соціальних відносин у суспільстві; про нову роль держави як учасника міжнародних фінансових відносин; про модернізацію державних фінансових інститутів і вдосконалення державного фрінансового управління в контексті децентралізації, бюджетного федералізму, використання штучного інтелекту та адитивних технологій тощо).

Різні течії та школи економічної науки розставляють неоднозначні акценти в питанні, що стосується визначення предмета теоретичного аналізу в межах публічних фінансів. Доцільно в умовах нового прагматизму виокремлювати три найбільш поширені методологічні позиції, на яких ґрунтуються спроби принципового поглиблення відповідних визначень.

Перша з них стосується розуміння публічних фрінансів як інструменту реалізації фрінансових інтересів державної скарбниці (казни). У цьому контексті публічні фрінанси пов'язані з державною діяльністю і прийняттям фінансових рішень щодо способів фінансування державних і місцевих видатків за рахунок податків та інших методів накопичення централізованих і децентралізованих фрінансових ресурсів держави.

У традиційному розумінні макроекономічних залежностей публічні фрінанси розуміють як заходи уряду, спрямовані на зниження безробіття чи інфляції через зміну державних і місцевих видатків бюджетів різних рівнів та позабюджетних фондів, фінансового стану державних і муніципальних корпорацій, рівня оподаткування чи мобілізації альтернативних доходів держави або через одночасне поєднання всіх цих заходів. У такому контексті доходи і державні та місцеві видатки - основні інструменти публічних фрінансів, які повинні 
мати стимулюючий / експансійний характер (спрямовані на підтримання високих темпів економічного зростання та досягнення високого рівня зайнятості через стимулювання сукупного попиту) та стримуючий / рестрикційний характер (зорієнтовані на скорочення сукупного попиту і зниження рівня інфрляції).

Принциповою позицією є те, що доцільно розглядати публічні фрінанси у широкому контексті - через призму прийняття фрінансових рішень щодо доходів казни і державних та місцевих видатків, не залишаючи при цьому поза увагою невід'ємну детермінанту цієї політики - державний борг як інструмент фрінансування дефіциту бюджетів, а в умовах сьогодення - повноцінний сегмент формування бюджетних ресурсів як державного, так і місцевого бюджетів.

Щоб окреслити визначальні детермінанти публічних фінансів на сучасному етапі глобальних європейських трансформацій, необхідно звернути увагу на ще один важливий, з методологічної точки зору, аспект. Йдеться, зокрема, про те, що глобальний європейський економічний розвиток як складова значно ширшої суспільно-історичної еволюції супроводжується посиленням та поглибленням диференціації і дезінтеграції глобального простору. У такому контексті особливості публічних фрінансів $є$ зовнішніми формами відображення об'єктивної дійсності у причинно-наслідкових формах глобалізації і диференціації.

Де-юре публічні фрінанси залишаються форпостом соціально-економічного суверенітету держави. Йдеться щонайменше про два таких основних аспекти. По-перше, одним із принципів правосуб'єктності держави і символом національного суверенітету з часів Вестфальського миру 1648 р. $€$ право кожної суверенної держави встановлювати і стягувати на своїй території податки. По-друге, основою економічного суверенітету $€$ бюджет як інструмент надання суспільних благ, як фрінансова основа економічної діяльності держави і виконання нею своїх основних функцій. । наскільки б інтенсивно не відбувалися процеси глобалізації, допоки є бюджет - існує держава, поки існує держава - існуватиме бюджет. Бюджетна політика традиційно залишається концентрованим відображенням основних функцій держави, а структура бюджету - її пріоритетів. На відповідній основі реалізуються і механізми управління публічними фінансами.

Сьогодні криза охопила глобальну соціальну сферу і переходить у сферу політичну (гібридні війни, загострення політичного протистояння у світовому масштабі, соціальні потрясіння, пандемії, глобальне потепління і проблеми з біженцями). Найгірше, що все це відображається на соціумі, і криза перейшла у сферу цінностей та ідеології. Необхідно переосмислити цілі глобального розвитку. Післякоронавірусний період та подолання наслідків кризи глобалізації вимагатимуть принципового перебудування фрормальних і неформальних інститутів, у межах яких функціонує світове господарство. Існуюча сьогодні система міжнародних інститутів сприяє радше глобальному хаосу, ніж глобальному порядку. Неспроможність соціально-економічної теорії сьогодні вибудувати постулати для практичної реалізації їі основних положень задля ефективного безкризового розвитку світової економіки ще раз підтверджує, що економіка майбутнього потребує нового теоретичного підґрунтя та побудови новітніх інститутів, які в комплексі дають змогу скоординувати у світовому масштабі і економіку, і політику у контексті врахування національних культурних особливостей та соціальної сфери (несормальних інститутів). 
Послаблення фрінансової політики держави як основного інструменту управління публічними фрінансами і стабілізації кон'юнктури в умовах глобальної нестабільності зумовило об'єктивну необхідність висунення нових концепцій фріскалізації публічних фрінансів. Дедалі частіше порушується питання про необхідність впровадження у фрінансову практику так званих "формальних інститутів фріскального простору" (йдеться про правила та норми, які затверджені законодавчо або прийняті у формі “суспільної угоди” і повинні стати критеріями фрінансової дисципліни й есрективної бюджетної політики). Необхідність прийняття цих інститутів зумовлена перманентно зростаючими бюджетними дефіцитами, державною заборгованістю і збільшенням видатків на обслуговування державного боргу, що однозначно негативно позначається на темпах економічного зростання і стабільності фінансових систем як розвинутих країн, так і країн з ринками, що розвиваються. Відкритим залишається питання про можливі позитивні і негативні наслідки, що можуть виникнути під час використання цих правил, порівняно з гнучкою (дискреційною) фрінансовою політикою, яка більш динамічно реагує і адаптується до зовнішньої економічної кон'юнктури. Інакше кажучи, предметом дискусії упродовж останніх кількох десятиліть залишається питання: яка політика більш ефективна - уніфікована, що базується на жорстких правилах, нормах і законах, чи дискреційна, в умовах якої рішення щодо вжиття тих чи інших заходів приймаються з урахуванням як цілей національної фінансової політики, інституціональної організації фіскального простору і методів реалізації бюджетної політики, так і зовнішньої економічної кон'юнктури.

Дедалі очевиднішим $є$ те, що бюджетний дефріцит, як і інші фріскальні параметри (доходи, видатки, державні і муніципальні борги), важливо розглядати не лише в статиці, а й у динаміці (як формування доходів бюджету, здійснення бюджетних видатків, фрінансування бюджетного дефріциту й обслуговування боргових зобов'язань держави), оскільки всі вони є відображенням процесів, що взаємопов'язано протікають у часі з різною інтенсивністю, збігаючись за напрямами чи різноспрямовано.

Кон'юнктурний фріскальний розрив як різниця (відхилення) фрактичних основних параметрів публічних фрінансів від потенційно запланованих виникає у результаті дії ендогенних і екзогенних асиметричних шоків / імпульсів, а циклічний фріскальний розрив (відхилення фріскальних параметрів від заданої тенденції з урахуванням чинника часу) $€$ наслідком стохастичних коливань ділової активності навколо тренда.

Незалежно від типу асиметричного шоку (чи то шок пропозиції, чи попиту), а також від того, які механізми його поширення, асиметричні шоки можуть виникати як усередині країни, так і за її межами. В умовах сучасної глобальної фази розвитку європейської економіки фрінансова система будь-якої країни через торговельні і фрінансові взаємозв'язки піддається впливу зовнішніх чинників і економічних подій, що відбуваються в інших країнах і регіонах. Відповідно, в аналітичних цілях за допомогою економетричних моделей важливо прораховувати вплив не лише ендогенного (в науковій літературі зустрічаємо "домашнього" [9, с. 591]), а й екзогенного (міжнародного) компонента стохастичних кон'юнктурних коливань і циклічних імпульсів. Кожен із таких екзогенних імпульсів чи асиметричних шоків поширюється в глобальній економіці, змінюючи фріскальні параметри публічних фрінансів окремих держав, причому спосіб поширення залежить від моделі соціальноекономічного розвитку кожної конкретної 
держави та структури її фрінансової системи.

В умовах поглиблення глобальних фріскальних дисбалансів і загострення проблеми фінансової кризи актуалізується питання збалансованого бюджету i забезпечення на цій основі стійкості публічних фрінансів. 3 огляду на моделі фіскальної рівноваги, сучасна фрінансова наука оперує п'ятьма основними концепціями збалансування бюджету, в рамках яких прописані теоретичні моделі прийняття фінансових рішень для забезпечення сталого розвитку суспільства:

1. Концепція збалансування бюджету на щорічній основі, суть якої полягає в необхідності щорічного збалансування бюджету на бездефріцитній основі.

2. Концепція циклічного збалансування бюджету, згідно з якою бюджет має бути збалансований не в календарному чи фрінансовому році, а протягом усього економічного циклу. У цьому випадку державні запозичення виступають інструментом фінансування бюджетного десіциту, що виникає в результаті скорочення доходів від оподаткування в депресивній фазі економічного циклу.

3. Концепція автоматично стабілізуючої економічної політики, що передбачає балансування бюджету протягом усього економічного циклу, проте увага акцентується у ній на так званих вмонтованих стабілізаторах.

4. Концепція компенсаційного бюджету, в якій наголошується на перманентно зростаючій стагнації економіки розвинутих країн і, відповідно, на неможливості зменшення постійно зростаючого дефіциту бюджету та повної відмови від державних запозичень.

5. Концепція фіскальної консолідації, науковий інтерес до якої зріс під впливом глобальної кризи 2008-2009 рр. і в умовах загострення боргових проблем у Греції, Іспанії, Ірландії і Португалії в 2010 р., масштабної світової пандемії 2019-2020 рр. В основу фрінансової політики більшості країн на найближчі роки покладено ідею забезпечення стабільності бюджетної системи за рахунок збільшення бюджетного дефіциту з умовою виконання раніше прийнятих боргових зобов'язань і сприяння інноваційному розвитку економіки. Така корекція фрінансової політики визначається щонайменше двома причинами. По-перше, подальше нарощування бюджетних видатків суперечить політиці забезпечення фінансової стабільності і стримування інфрляційних процесів. По-друге, накопичений у більшості країн за попередні періоди тягар соціальних зобов'язань і зростання його у часи кризи та пандемії буде збільшуватися, що виллється у більш жорстокі бюджетні та фріскальні правила та вимоги до скерування бюджетних коштів.

Як підтверджує практика розвинутих європейських країн, для досягнення фіскальної збалансованості і стійкості більшість із них застосовують формальні та неформальні інститути у вигляді спеціальних фіскальних правил. У 1990-ті рр. у більшості країн були підготовлені нормативні і методичні документи у сфері проведення бюджетної політики, розробки довгострокових бюджетних стратегій і досягнення бюджетної стійкості. Наприклад, у Великобританії був ухвалений “Кодекс бюджетної стабільності” (1997р.), Австралії - “Хартія бюджетної справедливості" (1998р.), Новій Зеландії - "Акт фріскальної відповідальності” (1994р.), Європейському Союзі - "Маастрихтська угода" (розширено в 1997 р. відповідно до "Пакту про стабільність і зростання") [10]. Узагальнюючи європей- 
ський досвід, автори одного із досліджень на цю тему виокремлюють три основних типи правил, що накладають обмеження на бюджетну політику з метою досягнення макроекономічної стабільності, зміцнення фрінансової надійності і довіри до публічних фрінансів та соціально-економічної політики уряду [11]:

1. Правила, що потребують збалансованого бюджету чи обмеження граничної величини бюджетного десріциту (зокрема, йдеться про такі форми фіскальних обмежень: повну відповідність доходів і видатків бюджету, тобто повну заборону державних запозичень, чи обмеження бюджетного дефіциту певним відсотком ВВП; збалансування доходів і видатків з урахуванням циклічного чинника (це саме стосується і обсягу бюджетного дефіциту); збалансування лише поточних доходів і видатків, при тому, що позики допускаються лише для фрінансування капіталовкладень);

2. Правила щодо політики державних i місцевих запозичень (можуть забороняти державні та муніципальні позики із внутрішніх джерел, у центрального банку, або ж обмежувати ці позики певною пропорцією до державних доходів і видатків у минулому).

3. Правила щодо обсягу державного боргу чи резервів (можуть обмежувати обсяг валової (або чистої) заборгованості відсотком у внутрішньому валовому продукті; визначати величину резервів позабюджетних фондів (найчастіше фондів соціального страхування) часткою щорічних соціальних виплат).

В умовах нестабільної зовнішньої кон'юнктури масштаби глобальних фіскальних дисбалансів закономірно зростають, проте їх наслідки (ефекти) в різних країнах суттєво відрізняються як за характером і причинами виникнення, так і за ре- гулярністю й тривалістю існування в часі тощо. На аналітичному рівні асиметричний характер ефектів фріскальних дисбалансів можна пояснити щонайменше 3 позицій трьох якісно різних точок зору.

По-перше, їх динаміка і форми вияву (йдеться про фріскальні дисбаланси) в країнах, які значною мірою залежать від умов зовнішньої торгівлі й зовнішнього фрінансування, відрізняються від тих, що наявні в країнах, менш залежних від зовнішнього світу. У такому разі можна спостерігати більший вплив невизначеності чинників зовнішнього середовища (наприклад, ціни на нафту і газ, валютної волатильності і нестабільного обмінного курсу, динаміки відсоткових ставок на ринках позикового капіталу та ін.) на державні фрінанси країн із надмірним рівнем залежності від них, що значною мірою зумовлений високою зовнішньоекономічною відкритістю (йдеться зокрема й про вітчизняну економіку).

По-друге, країни - експортери сировини і товарів з низьким рівнем обробки піддаються впливу іншого типу шоків, ніж країни - експортери готової високотехнологічної продукції. Як відомо, амплітуда коливань світових цін на сировину набагато вища, ніж на продукцію обробної галузі, що пов'язано як з обмеженістю природних запасів (наприклад, нафтти і газу), так і з недостатнім рівнем конкуренції на сировинних ринках, що мають олігополістичний характер. Щодо цін на товари з низьким рівнем обробки (наприклад, чорні і кольорові метали), то їх динаміка значною мірою визначається загальною світовою кон'юнктурою (у випадку погіршення умов торгівлі відбувається різке зниження цін на таку продукцію).

I наостанку, основні фріскальні параметри (доходи і видатки бюджету, бюджетний дефіцит і державний та муніципальний борг) можуть відрізнятися від цільових орієнтирів внаслідок того, що прогнози всіх основних 
макроекономічних показників містять систематичну помилку (чергування недооцінки певного показника з його переоцінкою свідчить про випадковий характер помилки прогнозування, натомість переважання завищених чи занижених прогнозів свідчить про їх систематичне відхилення від фрактичних показників), дія якої в умовах нестабільної зовнішньої кон'юнктури, як правило, посилюється. Світовий досвід показує, що різні країни у різні періоди застосовують як консервативне прогнозування параметрів публічних фрінансів (за якого, наприклад, прогнози бюджетних доходів цілеспрямовано занижують), так і оптимістичні підходи до прогнозування параметрів публічних фрінансів (коли прогнози бюджетних доходів, навпаки, цілеспрямовано завищують). Так, наприклад, А. Ауербах у своїй відомій роботі показав, що прогноз доходів федерального бюджету в США систематично занижували (консервативний підхід) при президентові Б. Клінтоні (в 1993-1999 рр.) і систематично завищували до нього (в 1986-1992рр.) [12]. Стійкі оптимістичні прогнози означають, що уряд, забезпечуючи короткострокові політичні цілі або тиск лоббіських груп, намагається невиправдано збільшити державні витрати. Це призводить до регулярного перевищення законодавчо встановлених показників бюджетного дефіциту, тобто до послаблення фрінансової дисципліни.

Беручи до уваги цінності, що змінюються, і нові вектори суспільного розвитку, зумовлені кризою глобалізації та пандемією, потрібно по-іншому підходити як до сутнісної природи публічних фрінансів, так і до інститутів їх фріскалізації. Нам потрібно навчитися співіснувати в теоретико-практичному ареолі трикутника рівноважного суспільного розвитку, урівноваженого сталим розвитком, а саме - новим прагматизмом соціального, екологічного та економічного розвитку. Своєю чергою новий прагматизм фріскалізації публічних фрінансів - це нормативний підхід, що в умовах виходу із кризи і подолання наслідків пандемії демонструє урівноваження та рівновіддалення вершин такого трикутника, які визначаються цінностями, формальними та неформальними інститутами і політикою. Для його більш глибокого сутнісного розуміння доречно виокремити вісім головних рис теорії збігу обставин розвитку Гжегоша Колодки:

1) відмова від будь-якого догматизму як інтелектуального корсету і фрактору, надто односторонньо спрямованого на пошук відповіді на конкретні питання;

2) неприйняття сліпого підпорядкування будь-якій ідеології чи політичній лінії без урахування викликів та загроз, але пошук об'єктивної істини без уступок повсякденним і консенсуальним істинам;

3) відмова від спроб створення універсальної теорії економічного росту і переключення уваги на специфічні риси явищ і процесів, нерозривно пов'язаних з макроекономічним відтворенням;

4) міждисциплінарний підхід, що накладає на хід економічного міркування досягнення з інших галузей, особливо історії, футурології, географії, права, соціології, психології, науки про управління, науки про Інтернет;

5) широке застосування порівняльного методу економічного аналізу;

6) переміщення в багатовимірному просторі, що складається з конкретних історичного, географрічного, культурного, інституціонального, політичного, соціального і проблемного вимірів;

7) відокремлення цілей діяльності від засобів їх досягнення;

8) інструментальна гнучкість, відкрита для рівнонаправлених пошуків превентивних заходів, що підходять для конкретної специфрічної ситуації. 
Теорія збігу обставин розвитку, якщо тільки буде відповідним чином, 3 одного боку, розвинута, а з іншого - конкретно зорієнтована на окремі види викликів розвитку, послугує чудовою основою для прагматичних дій, спрямованих на вирішення конкретних проблем [13].

Побудова оптимальної моделі фріскалізації публічних фрінансів потребує дослідження концептуальних основ, конкретних форм і методів довгострокового та короткострокового впливу інститутів фіскального простору на розвиток суспільства. Останні мають узгоджуватися із соціальними й економічними проблемами в державі, можливостями їх вирішення через політику доходів бюджетів і міжбюджетних трансфертів в умовах децентралізації, політику державних і місцевих позабюджетних фондів, фінансову політику державних і муніципальних комунальних корпорацій, політику боргових фрінансів та політику бюджетного регулювання й орієнтуватися на історичні, національні, культурні особливості, ступінь участі держави в соціально-економічних процесах, розвиненість ринкових відносин.

Управління публічними фінансами кожної країни має свої особливості ще й з погляду того, що на неї має впливати менталітет суспільства - сформована століттями свідомість людей. Справа не в тому, що надмірна фіскалізація публічних фрінансів чи скорочення видатків в одній країні буде сприйматися позитивно, а в іншій - ні. Йдеться про форми та способи вияву психологічної реакції на фіскальні дії держави. Якщо національний тип охарактеризовано як впертий індивідуалізм, то соціально-економічні агенти країни будуть опиратися діям держави, захищаючи свої інтереси доти, доки це буде можливо. Про це потрібно пам'ятати, розглядаючи можливі перспективи застосування фінансових інструментів для перезавантаження публічних фрінансів.
Висновки. Новий прагматизм фріскалізації публічних фрінансів в умовах зміни технологічного укладу виступає логічним продовженням розуміння необхідності переосмислення призначення і ролі держави у суспільному розвитку.

Реалії сучасного соціально-економічного буття показують, що не капітал диктуватиме умови національним урядам і органам місцевого самоврядування, а розвинуті міждержавні і національні бюрократичні машини, які маніпулюють думками мільйонів, будуть диригувати суспільством. Це зовсім не означає, що ми йдемо до комунізму. Приватна власність залишиться у фундаменті суспільного базису, проте приватний капітал не здатен боротися $з$ наслідками світових фінансових криз, нелегальною імміграцією, пандеміями чи глобальним потеплінням. Вирішення макропроблем стабілізації публічних фрінансів, що зачіпають інтереси усіх без винятку, вимагає деякого обмеження індивідуальної свободи. В цьому сенсі людство рухатиметься в майбутнє, зазираючи у минуле, відділяючись від ліберальної мрії абсолютної свободи.

\section{Список використаних джерел}

1. Колодко Г. В. Мир в движении. Москва : Магистр, 2009. 576 c.

2. Фінанси зарубіжних країн : навч. посіб. / Кізима Т. О., Кравчук Н. Я., Горин В. П. та ін. ; за ред. О. П. Кириленко. Тернопіль : Економічна думка, 2013. 287c.

3. Длугопольський О. В. Теорія економіки державного сектору : навч. посіб. Тернопіль : Економічна думка, 2007. 488 c.

4. Сутормина В. Н. Финансы капиталистических государств. Київ : Вища школа, 1983. $311 \mathrm{c}$.

5. Суторміна В. М., Федосов В. М., Андрущенко В. Л. Держава - податки - бізнес (із світового досвіду фріскального регулювання ринкової економіки): Київ : Либідь, 1992. 328 с. 


\section{АКТУАЛЬНІ ПИТАННЯ ТЕОРІЇ І ПРАКТИКИ ФІНАНСІВ}

6. Глобализация мирового хозяйства : уч. пособ. / под ред. д-ра экон. наук, проф. М. Н. Осьмовой, канд. экон. наук, доц. А. В. Бойченко. Москва : ИНФРА-М, 2006. 376 с.

7. Шишков Ю. Государство в эпоху глобализации. Мировая экономика и мировые отношения. 2010. № 1. С. 3-13.

8. Андрущенко В. Л. Фінансова думка Заходу в XX столітmі (Теоретична концептуалізація і наукова проблематика державних фрінансів). Львів : Каменяр, 2000. 305 с.

9. Сакс Дж. Д., Фелипе Ларрен Б. Макроэкономика. Глобальный подход ; пер. с англ. под ред. С. М. Мовшовича, А. А. Фридмана, М. И. Левина. Москва : Дело, 1996. 848 с.

10. Тимохина Е. Анализ устойчивости Федерального бюджета России в период кризиса. Вопросы экономики. 2011. № 1. С. 26.

11. Kopits G., Symansky S. Fiscal Rules // Occasional Papers. 1998. № 162. P. 20-23.

12. Auerbach $A$. On the performance and use of government revenue forecasts. National Tax Journal. 1999. Vol. 52. No 4.

13. Колодко Г. В. Глобализация, трансформация, кризис - что дальше? Москва : Маzucmp, 2011. 177 c.

\section{References}

1. Kolodko, G. (2009). Mir v dvizhenii [World in motion]. Moscow: Magistr [in Russian].

2. Kizyma, T. O., Kravchuk, N. Ya., Horyn, V. P. Kyrylenko, O. P. (Ed.). (2013). Finansy zarubizhnykh krain [Finance of foreign countries]. Ternopil: Ekonomichna dumka [in Ukrainian].

3. Dluhopolskyi, O. V. (2007). Teoriia ekonomiky derzhavnoho sektory [Theory of public sector economics]. Ternopil: Ekonomichna dumka [in Ukrainian].

4. Sutormina, V. N. (1983). Finansy kapitalisticheskikh gosudarstv [Finance of capitalist states]. Kyiv: Vyshcha shkola [in Russian].

5. Sutormina, V., Fedosov, V., Andrushchenko, V. (1992). Derzhava - podatky - biznes (iz svitovoho dosvidu fiskalnoho rehuliuvannia rynkovoi ekonomiky) [State - taxes - business (from global experience of regulating market economy)]. Kyiv: Lybid [in Ukrainian].

6. Osmova, M., Boichenko, A. (Ed.). (2006). Globalizatsiya mirovogo khozyaystva [Globalization of world economy]. Moscow: INFRA-M [in Russian].

7. Shyshkov, Yu. (2010). Gosudarstvo v epokhu globalizatsii [State in the era of globalization]. Mirovaya ekonomika i mezhdunarodnye otnosheniya - World Economy and International Relations, 1, 3-13 [in Russian].

8. Andrushchenko, V. (2000). Finansova dumka Zakhodu v XX stolitti (Teoretychna kontseptualizatsiia i naukova problematyka derzhavnykh finansiv) [Financial thought in the West in the 21st century (Theoretical conceptualization and scientific problems of state finance)]. Kyiv: Kameniar [in Ukrainian].

9. Sachs, J. D. (1996). Makroekonomika. Globalnyi podkhod [Macroeconomics. Global approach]. (S. Movshovych, A. Frydman, M. Levyn, Trans.). Moscow: Delo [in Russian].

10. Tymokhina, E. (2011). Analiz ustoychivosti Federalnogo byudzheta Rossii v period krizisa [Ananlysis of the stability of the Russian federal budget in period of crisis]. Voprosy ekonomiki Economic Issues, 1, 26-38 [in Russian].

11. Kopits, G., Symansky, S. (1998). Fiscal policy rules. Occassional Papers, 162, 45.

12. Auerbach, A. (1999). On the performance and use of government revenue forecasts. National Tax Journal, (4), 767-782 (Vol. 52).

13. Kolodko, G. (2011). Globalizatsiya, transformatsiya, krizis - chto dalshe? [Globalization, transformation, crisis - what's next?]. Moscow: Magistr [in Russian].

Стаття надійшла до редакції 16.11.2020. 